\title{
Pembelajaran Berbasis Masalah Dengan Strategi Konflik Kognitif Terhadap Penguasaan Konsep Dan Kemampuan Berpikir Kritis Fisika Siswa Kelas XI SMKN 1 Lingsar Tahun Pelajaran 2015/2016
}

\author{
Nurul Fatimah, Gunawan, Wahyudi \\ Program Studi Pendidikan Fisika \\ FKIP Universitas Mataram \\ Mataram, Indonesia \\ Email: nurul.fatimah0409@gmail.com
}

\begin{abstract}
This study aimed to determine the effect of the problem based learning with cognitive conflict strategy towards mastery of concepts and critical thinking skills physics class XI ${ }^{\text {th }}$ at SMKN 1 Lingsar academic year 2015/2016. Mastery of concepts measured on the cognitive domain of C1 through C6 (knowledge, comprehension, application, analysis, evaluation and creation) and critical thinking skills measured by indicators of critical thinking. Type of research is a quasi-experimental research design pretest-posttest control group design. Sampling using random cluster sampling. Classroom study is a class XI TI as an experimental class with 36 people and the number of students in class XI TI 2 as the control class with the number of students 36 people. The data will be analyzed using one way MANOVA.. The results showed that the model of problem-based learning with cognitive conflict strategiy affect the mastery of concepts and critical thinking skills physics class X SMKN 1 Lingsar.
\end{abstract}

Keywords: problem-based learning model, cognitive conflict strategies, mastery of concepts, critical thinking.

\section{PENDAHULUAN}

Pendidikan dilaksanakan dengan tujuan untuk mempersiapkan peserta didik agar mampu bersaing dalam kehidupan bermasyarakat. Pendidikan di dalam sekolah memiliki peran yang sangat penting untuk mempersiapkan peserta didik sebaik-baiknya. Terkait dengan perkembangan zaman, pendidikan haruslah mampu memfasilitasi peserta didik untuk dapat bersaing sesuai dengan perkembangan zamannya.

Model pembelajaran yang memusatkan kegiatan pada pendidik menuai banyak kritik disebabkan model yang berpusat pada pendidik cenderung membuat peserta didik menjadi pasif dalam proses pembelajaran. Dengan membiarkan peserta didik pasif dalam proses pembelajaran akan membuat mereka sulit untuk mengembangkan kecakapan berpikir, kecakapan intrapersonal, kecakapan beradaptasi dengan baik sehingga model pembelajaran yang berpusat pada pendidik harus dihindari [1].

Namun pada kenyataannya, jarang sekali seorang pendidik dalam proses pembelajaran mengaitkan materi yang diajarkan dengan kehidupan peserta didik. Pendidik lebih banyak menekankan pembelajaran kepada materi ajar yang memungkinkan peserta didik memiliki kemampuan untuk sebatas dapat menjawab soal.

Hal ini tidak sesuai dengan hakikat belajar itu sendiri. Belajar adalah proses perubahan perilaku, berkat interaksi dengan lingkungannya. Perubahan perilaku mencakup aspek kognitif, afektif dan psikomotor. Adapun yang dimaksud lingkungan mencakup keluarga, sekolah, dan masyarakat, dimana peserta didik berada [2].

Pembelajaran yang memisahkan antara materi yang diajarkan disekolah dengan fenomena yang terjadi dilingkungan menyebabkan pemahaman peserta didik menjadi tidak menyeluruh dan dangkal. Peserta didik hanya menghafal rumus dan kemampuannya hanya terbatas pada menjawab soal ujian. Oleh karena itu dibutuhkan sebuah model pembelajaran yang memungkinkan peserta didik mengkonstruksi pemahamannya berdasarkan pemahaman awalnya atau berdasarkan fenomena yang sudah akrab dengan kehidupannya. Model pembelajaran berbasis masalah merupakan salah satu model pembelajaran yang cocok untuk mengatasi permasalahan ini.

Salah satu keunggulan model pembelajaran berbasis masalah ialah model ini membangun pengetahuan dengan memperhitungkan pengetahuan sebelumnya. Masalah yang dirancang, dapat membangun kembali pemahaman peserta didik atas pengetahuan yang telah didapat sebelumnya. Jadi, sementara pengetahuanpengetahuan baru didapat, peserta didik juga dapat melihat kaitannya dengan bahan yang telah ditemukan dan dipahami sebelumnya [1].

Model pembelajaran berbasis masalah merupakan suatu pendekatan pembelajaran di mana peserta didik mengerjakan permasalahan yang autentik dengan 
maksud untuk menyusun pengetahuan mereka sendiri, mengembangkan inkuiri dan keterampilan berpikir tingkat tinggi, mengembangkan kemandirian, dan percaya diri [3].

Menurut teori Piaget, peserta didik membangun pemahamannya berdasarkan eksplorasi dan interaksinya dengan teman-temannya, orang dewasa disekitarnya, serta dengan benda-benda yang ada di lingkungannya[4]. Dalam teori Piaget, peserta didik bukanlah kertas kosong yang siap dituliskan apa saja dikarenakan peserta didik terlebih dahulu sudah memiliki pengetahuannya sendiri sebelum memasuki dunia sekolah. Pengetahuan yang ada di dalam pikiran peserta didik dikonstruksi berdasarkan pengalaman, pembelajaran yang didapatkan sebelumnya, fenomenafenomena lingkungan dan lain sebagainya bukan semata-mata diturunkan langsung oleh pendidik.

Pengetahuan awal yang sudah ada dalam pikiran peserta didik ini berpengaruh pada pengetahuan yang akan didapat peserta didik ketika mengikuti proses pembelajaran karena pengetahuan yang akan didapat peserta didik ketika mengikuti proses pembelajaran akan dikonstruksi juga dari pengetahuan awal peserta didik. Pengetahuan awal atau prior knowledge yang merupakan kumpulan dari pengetahuan dan pengalaman individu yang diperoleh sepanjang perjalanan hidup mereka, dan apa yang ia bawa kepada suatu pengalaman belajar baru. Pengetahuan awal peserta didik menentukan kemungkinan-kemungkinan pembelajaran baru, yaitu, pengetahuan baru yang spesifik berupa fakta, konsep, dan keterampilan tidak dapat dipelajari sampai suatu dasar berupa pengetahuan terkait telah dipahami[5].

Dengan model pembelajaran berbasis masalah yang diterapkan menggunakan strategi konflik kognitif, maka peserta didik akan dapat mengkonstruksi pengetahuannya sendiri secara menyeluruh. Pemahaman yang didapatkan peserta didik dari fenomena lingkungan sekitarnya dan dengan pemahaman dalam proses pembelajaran akan berpadu menjadi suatu pemahaman yang bersifat menyeluruh. Peserta didik mencari sendiri pemahamannya dan mengkonstruksinya menjadi pemahaman yang utuh dan menyeluruh sehingga akan meningkatkan penguasaan konsep dan kemampuan berpikir tingkat tinggi peserta didik.

Berdasarkan uraian di atas, peneliti tertarik untuk melakukan penelitian berjudul "Pengaruh Model Pembelajaran Berbasis Masalah dengan Strategi Konflik Kognitif Terhadap Penguasaan Konsep dan Kemampuan Berpikir Kritis Siswa Kelas XI SMKN 1 Lingsar Tahun Ajaran 2015/2016".

\section{TINJAUAN PUSTAKA}

\section{A. Pengertian Model Pembelajaran Berbasis Masalah}

Model pembelajaran berbasis masalah merupakan suatu model pembelajaran yang didasarkan pada permasalahan nyata yang membutuhkan penyelidikan autentik yakni penyelidikan yang membutuhkan penyelesaian nyata [3]. Model pembelajaran berbasis masalah dapat diartikan sebagai konsepsi dari pengetahuan, pemahaman dan pendidikan yang sangat berbeda dari konsep pada umumnya yang mendasari pembelajaran berbasis subjek [6]. Model pembelajaran berbasis masalah merupakan sebuah pengembangan kurikulum dan metode pembelajaran yang menempatkan peserta didik dalam peran aktif sebagai pemecah masalah dengan dihadapkan dengan masalah nyata dan juga menarik untuk diselesaikan. [7].

Dari berbagai pengertian di atas dapat disimpulkan bahwa model pembelajaran berbasis masalah merupakan sebuah model pembelajaran yang menyajikan masalah yang bersifat nyata (autentik) dan menarik untuk dipecahkan oleh peserta didik sehingga peserta didik membangun sendiri pengetahuannya mengembangkan keterampilan berpikir tingkat tinggi, kemandirian, dan percaya diri.

\section{B. Karakteristik 'Masalah' dalam Model Pembelajaran Berbasis Masalah}

Masalah dalam model pembelajaran berbasis masalah memiliki karakteristik dimana siswa bekerja dengan pasangan atau kelompok untuk menginvestigasi masalah nyata yang menarik untuk diselesaikan[8]. Sejalan dengan pendapat tersebut, maka masalah dalam model pembelajaran berbasis masalah ialah merupakan masalah yang menarik untuk diselesaikan dan juga merupakan masalah yang berkaitan dengan kehidupan sehari-hari peserta didik. Situasi masalah yang baik seharusnya autentik, mengandung teka-teki, dan tidak didefinisikan secara ketat, memungkinkan kerjasama, bermakna bagi peserta didik, dan konsisten dengan tujuan kurikulum [3]. Masalah yang baik harus memenuhi lima sarat berikut. Pertama, masalah itu haruslah bersifat autentik. Kedua, masalah yang disajikan harus menarik untuk dipecahkan. Ketiga, masalah harus bermakna bagi peserta didik dan sesuai dengan perkembangan tingkat intelektual peserta didik. Keempat, cakupan masalah cukup luas hingga memungkinkan guru untuk mencapai tujuan instruksional namun masalah tersebut juga harus sesuai dengan keterbatasan waktu, ruang, dan sumberdaya. Terakhir, sebuah masalah yang baik harus memberi manfaat bagi kelompok bukannya merugikan [8].

Beberapa bentuk penyajian masalah yang dapat digunakan pendidik, yaitu 1) Kinerja yang tidak sesuai; 
2) Situasi yang menuntut perhatian atau peningkatan; 3) Mencari cara yang lebih baik atau hal yang baru; 4) Fenomena yang masih menjadi misteri atau belum dapat dijelaskan; 5) Adanya kesenjangan dalam informasi dan pengetahuan; 6) Masalah pengambilan keputusan [1].

\section{Sintaks Model Pembelajaran Berbasis Masalah}

Sintaks model pembelajaran berbasis masalah) ialah a) Mengorientasikan peserta didik pada masalah; b) Mengorganisasikan peserta didik agar belajar; c) Memandu menyelidiki secara mandiri atau kelompok; d) Mengembangkan dan menyajikan hasil kerja; serta e) Menganalisis dan mengevaluasi hasil pemecahan masalah [6].

\section{Pengertian Strategi Konflik Kognitif}

Strategi-strategi belajar mengacu pada perilaku dan proses-proses berpikir yang digunakan oleh peserta didik yang mempengaruhi apa yang dipelajari, termasuk proses memori dan metakognitif [5]. Konflik kognitif ialah suatu kondisi dimana peserta didik menemui pengalaman baru yang tidak tertata rapi dalam struktur kognitifnya [4]. Agar terjadi perubahan konseptual maka peserta didik harus dihadapkan pada konsep baru yang tidak konsisten dengan model mental yang dimilikinya. Peserta didik tersebut harus mengalami rasa tidak nyaman atau mengalami konflik kognitif, maka kemudian peserta didik akan menerima konsep baru ternyata dapat dipercaya dan dapat dipergunakan pada situasi lain sehingga akhirnya peserta didik akan mengganti konsep lama dengan konsep baru [4].

Dari uraian diatas maka dapat disimpulkan bahwa strategi konflik kognitif merupakan strategi yang digunakan dalam pembelajaran dimana peserta didik dihadapkan dengan suatu permasalahan atau pengetahuan baru yang kontras dengan pemahaman yang telah dimilikinya sehingga terjadi konflik kognitif yang memungkinkan terciptanya pengetahuan baru yang menggantikan pengetahuan lama.

\section{E. Proses Konflik Kognitif}

Hal-hal yang dapat dilakukan untuk mengorganisasikan peserta didik disebut sebagai skema yang merupakan kumpulan tindakan dan pikiran yang serupa, yang digunakan secara berulang dalam rangka merespon lingkungan. Pada awalnya skema-skema tersebut bersifat motorik, namun seiring berlalunya waktu menjadi lebih bersifat mental dan akhirnya abstrak. Seiring berlalunya waktu, skema-skema yang dimiliki peserta didik akan dimodifikasi melalui pengalaman dan menjadi terintegrasi satu sama lain [9].

Skema bisa berubah, dan perubahan seperti itu penting artinya dalam perkembangan kognitif. Proses berubahnya skema disebut dengan akomodasi yang dipengaruhi oleh proses asimilasi [10]. Skema berubah melalui proses adaptasi melalui asimilasi dan akomodasi [4].

Akomodasi merupakan modifikasi dari skema agar informasi yang baru dan kontradiktif bisa diterjemahkan. Informasi yang telah terkumpul dan dikelompokkan dalam skema-skema yang telah ada sebelumnya kemudian dimofikasi menjadi suatu skema (pengetahuan) baru. Sedangkan asimilasi adalah pengumpulan dan pengelompkan informasi baru[7]. Peserta didik dalam proses pembelajaran akan mendapatkan informasi baru yang kemudian akan dikumpulkan dan dikelompokkan ke dalam skema yang telah ada. Informasi tersebut hanya bisa diasimilasikan jika tidak ada kontradiksi terhadap sesuatu hal yang sudah ada, yang merupakan bagian penting dari apa yang sudah ada di dalam skema peserta didik yang bersangkutan.

Proses asimilasi meliputi penggunaan informasi baru dan mengubah informasi baru tersebut agar sesuai dengan skema atau model mental yang telah ada. Sedangkan proses akomodasi meliputi perubahan skema atau skema dimodifikasi suapaya sesuai dengan informasi baru [4].

Asimilasi dan akomodasi lazimnya beroperasi bersama-sama seiring berkembangnya pengetahuan dan pemahaman peserta didik terhadap dunia di sekelilingnya. Peserta didik menafsirkan setiap peristiwa baru dalam konteks pengetahuan yang telah mereka miliki (asimilasi) namun pada saat yang sama mungkin memodifikasi pengetahuan mereka sebagai hasil dari suatu periswtiwa baru (akomodasi). Akomodasi jarang terjadi tanpa asimilasi: peserta didik dapat mendapatkan manfaat atau mengakomodasi pengalaman-pengalaman baru hanya jika mereka dapat menghubungkan pengalaman-pengalaman tersebut dengan pengetahuan dan keyakinan yang mereka miliki pada saat itu [9].

Ketika sebuah skema berlangsung stabil dan bisa dengan mudah mengasimilasikan pengalaman baru yang relevan yang terjadi adalah keadaan ekuilibrium. Jika pada akhirnya terjadi akomodasi, sehingga skema yang baru bisa mengasimilasikan pengalamanpengalaman sulit ini hasilnya adalah suatu ekuilibrium [10]. Proses adaptasi skema akan terjadi apabila peserta didik menghadapi fenomena yang bertentangan dengan pemahaman yang selama ini diyakininya benar. Mereka mempertimbangkan fenomena baru, membuat penyesuaian-penyesuaian dalam struktur kognitifnya untuk mengakomodasikan situasi baru tersebut[4]. Hal inilah yang menghasilkan pembelajaran yang disebut juga ekuilibrium. Dimana dalam keadaan ekuilibrium 
seseorang merasa nyaman dengan pemahaman yang dimilikinya.

\section{F. Model Pembelajaran Berbasis Masalah dengan Strategi Konflik Kognitif}

Model Pembelajaran berbasis Masalah dengan strategi konflik kognitif ini menggunakan sintaks pembelajaran berbasis masalah dengan masalah yang digunakan merupakan masalah yang dapat menimbulkan konflik kognitif pada siswa. Pemberian masalah dalam model pembelajaran berbasis masalah didasarkan pada teori konflik kognitif dimana masalah yang ditimbulkan haruslah dekat dengan peserta didik dan menarik untuk diselesaikan.

\section{G. Penguasaan Konsep}

Konsep merupakan metode untuk mengelompokkan dan mengkategorikan secara mental berbagai objek atau peristiwa yang mirip dalam hal tertentu. Selain itu, konsep juga kadang-kadang memadatkan berbagai macam informasi menjadi sebuah entitas tunggal dan karena itu dapat mengurangi beban memori kerja yang memang kapasitasnya rendah [11]. Adapun penguasaan konsep merupakan penguasaan terhadap abstraksi yang memiliki satu kelas atau objek-objek kejadian atau hubungan yang mempunyai atribut yang sama. Menurut Piaget pertumbuhan intelektual manusia terjadi karena adanya proses kontinu yang menunjukkan equilibrium, sehingga akan tercapai tingkat pekembangan intelektual yang lebih tinggi [12].

Penguasaan konsep merupakan usaha yang dilakukan peserta didik dalam merekam dan mentrasnfer kembali sejumlah informasi dari suatu materi tertentu yang dapat digunakan dalam memecahkan masalah, menganalisa, menginterpretasikan pada suatu kejadian tertentu [13].

Pada penelitian ini indikator penguasaan konsep yang digunakan ialah indikator menurut taksonomi Bloom edisi revisi. Perbedaan taksonomi Bloom yang sebelumnya dengan taksonomi edisi revisi adalah pada taksonomi Bloom hanya mempunyai satu dimensi, sedangakan taksonomi revisinya memiliki dua dimensi. Dua dimensi tersebut adalah proses kognitif dan pengetahuan. Dimensi proses kognitif berisikan enam kategori yaitu mengingat, memahami, mangaplikasikan, menganalisis, mengevaluasi, dan mencipta [14].

\section{H. Pengertian Kemampuan Berpikir Kritis}

Berpikir kritis merupakan aktivitas aktif yang terampil terhadap observasi dan komunikasi, informasi dan argumentasi [15]. Berpikir kritis sebagai ialah "proses aktif" dan "cara berpikir secara teratur atau sistematis" untuk memahami informasi secara mendalam, sehingga membentu sebuah keyakinan kebenaran informasi yang didapat atau pendapat yang disampaikan [16].
Berpikir kritis dimaksudkan untuk menggali kejelasan dengan mempertanyakan segala hal yang berhubungan dengan informasi yang diperoleh secara detail, sehingga ditemukan kebenaran atas informasi yang disampaikan dan menghasilkan kesimpulan secara objektif [16].

\section{Indikator Kemampuan Berpikir Kritis}

Adapun indikator berpikir kritis mencakup berbagai indikator seperti pada tabel berikut [17].

Tabel 1 Indikator-indikator Berpikir Kritis

\begin{tabular}{cl}
\hline No & \multicolumn{1}{c}{ Indikator } \\
\hline 1. & Keputusan dan Argumen \\
2. & Menganalisis argument \\
3. & Mempertimbangkan kredibilitas sumber \\
4. & Mengobservasi dan mempertimbangkan \\
5. & Mendeduksi dan menilai hasil deduksi \\
6. & Menginduksi dan mempertimbangkan \\
7. & Membuat dan menilai hasil pertimbangan \\
8. & Mendiagnosis dan menemukan kesalahan \\
dalam eksperimen \\
10. Mengidentifikasi asumsi-asumsi \\
11. Meneralisasi \\
12. Mendefinisikan \\
13. Mempertimbangkan suatu definisi \\
14. Aplikasi berpikir kritis : berinteraksi \\
\hline
\end{tabular}

Pada penelitian, indikator berpikir kritis yang diuji mencakup 1) merumuskan kriteria untuk mempertimbangkan kemungkinan jawaban, 2) merumuskan hipotesis, 3) menarik kesimpulan sesuai fakta, 4) mengidentifikasi alasan yang mendukung argumen, 5) kemampuan memberikan alasan.

\section{METODE PENELITIAN}

Penelitian ini termasuk penelitian quasi experimental. Penelitian dilakukan pada di SMKN 1 Lingsar pada semester ganjil tahun pelajaran 2015/2016. Penelitian ini menggunkan dua kelas sampel yakni kelas eksperimen dann kelas control dengan masing-masing kelas berjumlah 36 siswa. Desain penelitian ini yaitu pretest and posttest control group design. Perlakuan dilakukan pada kelas eksperimen, sedangkan pembelajaran konvensional diterapkan pada kelas kontrol. Materi yang digunakan adalah suhu, kalor dan pemuaian. Pengolahan data diawali dari pengujian homogenitas, normalitas dan $\mathrm{N}$-gain data. Kemudian hipotesis diuji dengan uji MANOVA satu jalur dengan taraf signifikansi $5 \%$. 


\section{HASIL DAN PEMBAHASAN}

Hasil penelitian berupa data hasil tes awal dan tes akhir penguasaan konsep dan kemampuan berpikir kritis kelas eksperimen dan kelas control. Hasil tes peguasaan konsep dapat dilihat pada Tabel 2.

Tabel 2 Hasil Tes Penguasaan Konsep

\begin{tabular}{cccc}
\hline \multirow{2}{*}{ Kelas } & & Tes & Tes \\
& & Awal & Akhir \\
\hline \multirow{4}{*}{ Eksperimen } & Tertinggi & 43 & 93 \\
& Terendah & 20 & 53 \\
& Rata-rata & 32,17 & 76,40 \\
& SD & 6,49 & 8,43 \\
& Tertinggi & 50 & 83 \\
Kontrol & Terendah & 23 & 50 \\
& Rata-rata & 34,44 & 70,10 \\
& SD & 6,41 & 8,54 \\
\hline
\end{tabular}

Berdasarkan Tabel 2 dapat dilihat bahwa nilai ratarata kelas kontrol pada tes awal lebih tinggi sedangkan pada tes akhir didapatkan bahwa nilai rata-rata kelas eksperimen lebih tinggi. Data hasil penguasaan konsep ini kemudian diuji normalitas dan homogenitasnya. Setelah dilakukan uji normalitas dan homogenitas didapatkan bahwa data terdistribusi normal dan bersifat homogen.

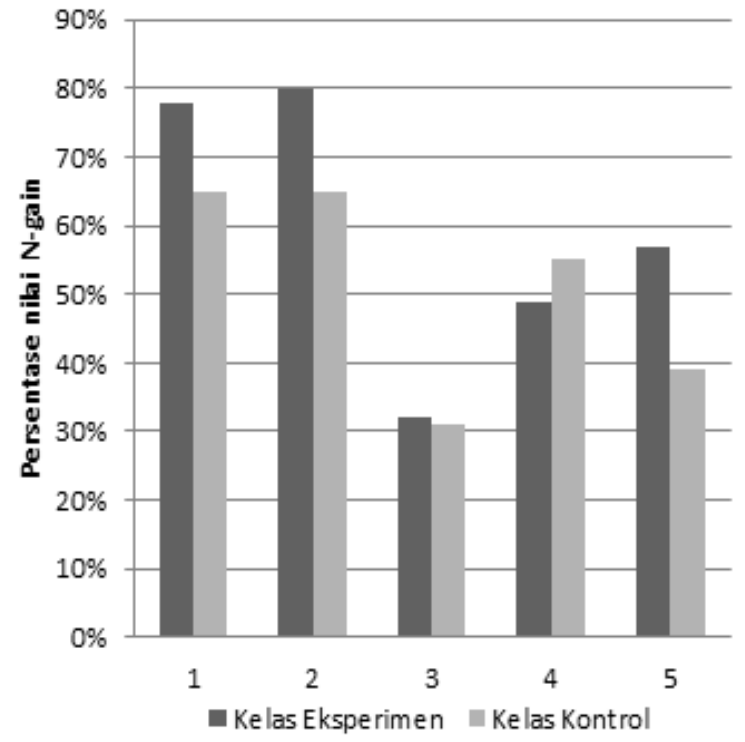

Gambar 1. Perbandingan Nilai N-gain Persub Materi Penguasaan Konsep

Peningkatan pada masing-masing kelas diuji dengan uji N-gain. Adapun uji N-gain yang dilakukan berdasarkan dari setiap sub materi yang diajarkan. Sub materi tersebut ialah (1) suhu, (2) kalor, (3) perubahan wujud zat (4) perpindahan kalor, (5) pemuaian. Dari Gambar 1 dapat dilihat bahwa peningkatan yang terjadi pada kelas eksperimen lebih tinggi dibandingkan pada kelas kontrol.
Hasil uji N-gain pada kelas eksperimen menunjukkan nilai yang lebih tinggi dibandingkan kelas kontrol secara keseluruhan. Adapun N-gain pada tiap sub materi lebih besar dibandingkan kelas kontrol kecuali pada sub materi perpindahan kalor. Lebih rendahnya peningkatan pada sub materi perpindahan kalor disebabkan karena pada sub materi ini, perhitungan yang digunakan lebih rumit dibandingkan materi lain. Pada proses pembelajaran, penyampaian materi pada kelas eksperimen berfokus pada upaya penyelesaian masalah sehari-hari yang berhubungan dengan materi suhu dan kalor sehingga pada kelas eksperimen sehingga waktu pemebelajaran yang tersedia untuk pembahasan contoh soal hitungan tidak sebanyak pada kelas kontrol. Kendala dari pelaksanaan penelitian ini terdapat pada kurangnya jam pelajaran yang tersedia sehingga waktu yang diperlukan untuk refleksi kurang.

Hasil tes kemampuan berpikir kritis berupa data hasil tes awal dan tes akhir kemampuan berpikir kritis kelas eksperimen dan kelas kontrol dapat dilihat pada Tabel 3.

Tabel 3 Hasil Tes Kemapuan Berpikir Kritis

\begin{tabular}{cccc}
\hline \multirow{2}{*}{ Kelas } & & $\begin{array}{c}\text { Tes } \\
\text { Awal }\end{array}$ & $\begin{array}{c}\text { Tes } \\
\text { Akhir }\end{array}$ \\
\hline \multirow{4}{*}{ Eksperimen } & Tertinggi & 46 & 88 \\
& Terendah & 17 & 53 \\
& Rata-rata & 29,44 & 65,47 \\
& SD & 8,43 & 7,25 \\
\multirow{5}{*}{ Kontrol } & Tertinggi & 42 & 79 \\
& Terendah & 13 & 38 \\
& Rata-rata & 33,17 & 56,83 \\
& SD & 6,83 & 8,68 \\
\hline
\end{tabular}

Berdasarkan Tabel 3 dapat dilihat bahwa nilai ratarata kelas kontrol pada tes awal lebih tinggi sedangkan pada tes akhir didapatkan bahwa nilai rata-rata kelas eksperimen lebih tinggi. Data hasil kemampuan berpikir kritis ini terdistribusi normal dan bersifat homogen. Kelas kontrol dan kelas eksperimen samasama menunjukkan peningkatan. Peningkatan pada kelas eksperimen lebih tinggi dibandingkan kelas kontrol.

Dari Gambar 2 dapat dilihat bahwa peningkatan yang terjadi pada kelas eksperimen lebih tinggi dibandingkan pada kelas kontrol pada setiap indikator berpikir kritis yang diujikan. Indikator berpikir kritis yang diujikan ialah 1) merumuskan kriteria untuk mempertimbangkan kemungkinan jawaban, 2) merumuskan hipotesis, 3) menarik kesimpulan sesuai fakta, 4) mengidentifikasi alasan yang mendukung argumen, 5) kemampuan memberikan alasan. 


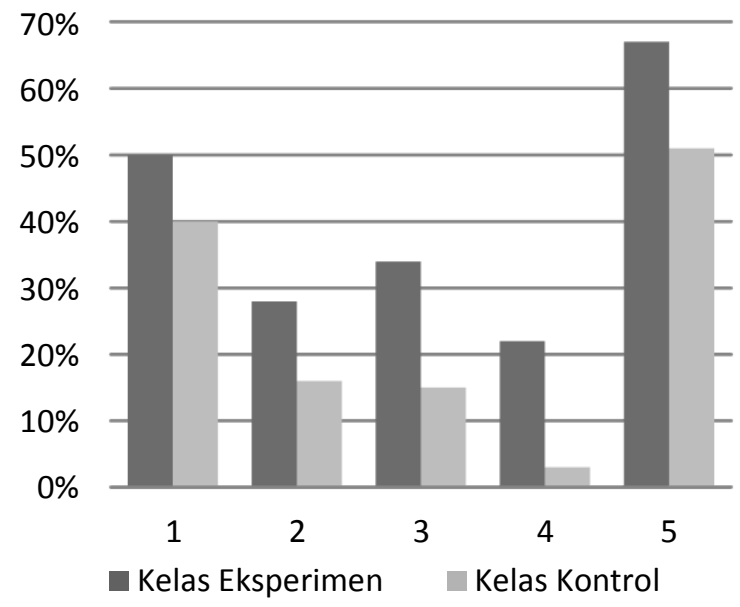

Gambar 2. Perbandingan Nilai N-gain Kemampuan Berpikir Kritis

Peningkatan kemampuan berpikir kritis peserta didik didapatkan dari hasil uji N-gainnya dimana pada setiap indikator nilai $\mathrm{N}$-gain kelas eksperimen lebih tinggi dibandingkan kelas kontrol. Peningkatan paling tinggi terdapat pada indikator kemampuan memberikan alasan. Pada indikator kemampuan memberikan alasan, kedua kelas sama-sama memiliki nilai $\mathrm{N}$-gain paling besar pada indikator ini. Selisih antara kelas kontrol dan kelas eksperimen yakni kelas eksperimen memiliki peningkatan $16 \%$ lebih tinggi dibandingkan kelas kontrol.

Peningkatan paling rendah kedua kelas ada pada indikator mengidentifikasi alasan yang mendukung argumen. Kedua kelas baik kelas eksperimen dan kontrol memiliki peningkatan paling rendah pada indikator ini. Adapun pada indikator menarik kesimpulan sesuai fakta dan mengidentifikasi alasan yang mendukung argumen, kelas eksperimen memiliki selisih paling besar dibanding kelas kontrol.

Uji MANOVA satu jalur digunakan untuk mengetahui pengaruh model pembelajaran berbasis masalah dengan strategi konflik kognitif terhadap kemampuan berpikir kritis fisika siswa. Data yang digunakan dalam ialah data tes akhir siswa. Setelah dilakukan uji hipotesis dengan MANOVA satu jalur, diketahui bahwa model pembelajaran berbasis masalah dengan strategi konflik kognitiif berpengaruh signifikan terhadap kemampuan berpikir kritis fisika siswa. Hasil uji hipotesis yang dilakukan dapat dilihat pada Tabel 4.

Tabel 4. Hasil Uji Hipotesis Menggunakan MANOVA Satu Jalur

Multivariate Tests ${ }^{c}$

\begin{tabular}{|c|c|c|c|c|c|c|c|c|}
\hline Effect & & Value & $\mathrm{F}$ & Hypothesis df & Error df & Sig. & $\begin{array}{l}\text { Noncent. } \\
\text { Parameter }\end{array}$ & $\begin{array}{c}\text { Observed } \\
\text { Power }\end{array}$ \\
\hline \multirow[t]{4}{*}{ Intercept } & Pillai's Trace & .963 & $906.460^{=}$ & 2.000 & 69.000 & .000 & 1812.920 & 1.000 \\
\hline & Wilks' Lambda & .037 & $906.460^{\beth}$ & 2.000 & 69.000 & .000 & 1812.920 & 1.000 \\
\hline & Hotelling's Trace & 26.274 & $906.460^{=}$ & 2.000 & 69.000 & .000 & 1812.920 & 1.000 \\
\hline & Roy's Largest Root & 26.274 & $906.460=$ & 2.000 & 69.000 & .000 & 1812.920 & 1.000 \\
\hline \multirow[t]{4}{*}{ model } & Pillai's Trace & .317 & $16.048=$ & 2.000 & 69.000 & .000 & 32.096 & .999 \\
\hline & Wilks' Lambda & .683 & $16.048^{2}$ & 2.000 & 69.000 & .000 & 32.096 & .999 \\
\hline & Hotelling's Trace & .465 & $16.048^{a}$ & 2.000 & 69.000 & .000 & 32.096 & .999 \\
\hline & Roy's Largest Root & .465 & $16.048^{a}$ & 2.000 & 69.000 & .000 & 32.096 & .999 \\
\hline
\end{tabular}

a. Exact statistic

b. Computed using alpha $=.05$

c. Design: Intercept + model

Berdasarkan Tabel 4, menunjukkan nilai analisis menggunakan manova untuk mengetahui pengaruh variabel bebas dengan variabel terikat. Penguasaan konsep dilambangkan dengan PK dan kemampuan berpikir kritis dengan BK. Dari hasil uji multivariat di atas, model dikatakan Signifikan apabila nilai Sig. $<0,05$. Kedua nilai baik pada penguasaan konsep (PK) dan kemampuan berpikir kritis (BK) menunjukkan masing-masing 0,000 sehingga kesimpulan dan jawaban hipotesis adalah model pembelajaran berbasis masalah dengan strategi konflik kognitif berpengaruh terhadap penguasaan konsep dan kemampuan berpikir kritis fisika siswa.
Model pembelajaran berbasis masalah dengan strategi konflik kognitif dilaksanakan dengan tahapan. 1) Orientasi peserta didik kepada konflik, 2) Mengorganisasikan peserta didik untuk belajar, 3) Membimbing penyelidikan individual maupun kelompok, 4) Mengembangkan dan menyajikan hasil karya, 5) Menganilisis dan mengevaluasi proses pemecahan konflik.

Orientasi peserta didik terhadap konflik merupakan aktivitas yang berada di awal pembelajaran dimana pada fase ini peserta didik diperkenalkan dengan fenomena-fenomena yang terjadi di sekitarnya, yang kemudian berdasarkan fenomena tersebut peserta didik 
akan dihadapkan dengan fenomena lain yang bertentangan dan atau dengan pertanyaan terkait fenomena tersebut. Sehingga diharapkan peserta didik melalui fase ini akan terjadi konflik di dalam pikirannya dan menyebabkan peserta didik mulai berpikir atau tertarik untuk menyelesaikan konflik yang terjadi.

Selanjutnya, peserta didik dibagi menjadi beberapa kelompok setelah atau sebelumnya dibagikan LKS dan diberi arahan terkait dengan metode yang dapat digunakan dalam menemukan penyelesaian konflik tersebut. Setelah itu peserta didik dibimbing untuk melakukan penyelidikan secara berkelompok. Peserta didik melakukan penyelidikan untuk mendapat penyelesaian dari konflik. Penyelidikan dilakukan dalam kelompok dimana sudah disediakan LKS untuk membantu peserta didik dalam menemukan penyelesaian konflik. LKS berisi serangkaian kegiatan percobaan dan daftar pertanyaan. Penyelidikan ini akan membuat peserta didik bekerja secara aktif, mengeksplorasi sumber pembelajaran dengan mandiri, selain itu usaha peserta didik dalam mencari penyelesaian konflik akan melatih peserta didik untuk mengkonstruksi pemikirannya, peserta didik akan mengkonstruksi pengetahuan lamanya sehingga terbentuk pengetahuan baru. Pengetahuan yang didapatkan akan lebih menyeluruh dan bermakna dibandingkan dengan pengetahuan yang didapatkan melalui ceramah dikelas seperti pada metode konvensional yang digunakan pada pembelajaran di kelas kontrol.

Pada kegiatan selanjutnya peserta didik mengembangkan dan menyajikan hasil karya. Hasil karya disini berupa hasil dari penyelidikan yang didapatkan dari serangkaian percobaan dan diskusi kelompok. Peserta didik berdiskusi mengenai hasil temuannya dan kemudian menyajikan hasil temuannya di depankelas. Kegiatan presentasi di depan kelas membuat peserta didik lebih bersungguh-sungguh dalam pembelajaran.

Kegiatan terakhir ialah menganilisis dan mengevaluasi proses pemecahan konflik. Penarikan kesimpulan berada setelah presentasi, penarikan kesimpulan berdasarkan temuan para peserta didik sendiri. Evaluasi diberikan dengan memberikan soal berupa lisan maupun tulisan sehingga dapat diketahui kemampuan peserta didik terhadap materi pembelajaran.

Dengan digunakan model pembelajaran berbasis masalah dengan strategi konflik kognitif dengan tahapan yang telah dijelaskan, akan membuat peserta didik lebih aktif sehingga kemampuan berpikir kritisnya lebih tinggi dibandingkan dengan pembelajaran dengan model konvensional. Pembelajaran yang membuat peserta didik mencari pengetahuannya sendiri akan membuat peserta didik lebih aktif dalam bekerja dan berpikir. Dalam proses berpikir, pengetahuan yang didapatkan peserta didik tidak bisa lepas dari pengetahuan yang telah didapatkan sebelumnya. Menjaga keterkaitan antara pengetahuan lama dengan pengetahuan yang akan diterima oleh peserta didik hingga akan menjadi pengetahuan baru peserta didik sangatlah penting. Maka dari itu model pembelajaran berbasis masalah dengan strategi konflik kognitif akan sangat baik digunakan untuk meningkatkan kemampuan berpikir kritis peserta didik. Mengajarkan pemikiran kritis disekolah seharusnya terarah pada keterampilan-keterampilan yang dibutuhkan dalam kehiduapn sehari-hari. Program berpikir kritis akan lebih efektif bila program itu bersifat "domain specific" (berisi hal-hal yang berkaitan langsung dengan masalah atau bidang khusus tertentu) dari pada bersifat "domain general"[14].

Temuan dalam penelitian ini memperkuat beberapa penelitian yang di lakukan sebelumnya oleh beberapa peneliti. Baser (2006) menyatakan bahwa penggunaan strategi konflik kognitif dapat meningkatkan penguasaan konsep pada materi perpindahan kalor dibandingkan dengan metode konvensional. Menurut Simanjuntak (2014), model pembelajaran berbasis masalah efektif untuk meningkatkan penguasaan konsep pada materi suhu dan kalor. Redhana (2013) menyatakan bahwa model pembelajaran berbasis masalah mampu meningkatkan kemampuan berpikir kritis peserta didik. Ismaimuza (2010) menyatakan kemampuan berpikir kritis peserta didik dengan model pembelajaran berbasis masalah dengan strategi konflik kognitif lebih baik daripada peserta didik yang memperoleh pembelajaran konvensional.

\section{PENUTUP}

Berdasarkan hasil penelitian dan pembahasan, maka dapat disimpulkan bahwa model pembelajaran berbasis masalah dengan strategi konflik kognitif berpengaruh terhadap kemampuan berpikir kritis fisika pada peserta didik kelas XI SMKN 1 Lingsar tahun ajaran 2015/2016. Pembelajaran dengan menerapkan model pembelajaran berbasis masalah dengan strategi konflik kognitif lebih baik dalam meningkatkan penguasaan konsep dan kemampuan berpikir kritis fisika peserta didik daripada pembelajaran konvensional.

Hal-hal yang perlu diperhatikan dalam penerapan model ini ialah:

1. Masalah yang diberikan haruslah akrab dengan siswa dan mampu menciptakan konflik dalam pikiran siswa. 
2. Alokasi waktu yang ditetapkan untuk setiap sub materi haruslah sebaik mungkin agar tiap tahap pembelajaran dapat dilakukan secara maksimal.

\section{UCAPAN TERIMAKASIH}

Terima kasih penulis ucapkan kepada bapak Ruju Rahmad, S.Pd.,MT, selaku kepala sekolah yang telah memberikan izin penelitian dan fasilitas yang diberikan, Ibu Irpiani Kusuma Dewi, S.Si., selaku guru mata pelajaran fisika, dan seluruh siswa kelas XI TI (Teknik Informatika) 1 dan XI TI (Teknik Informatika) 2 tahun pelajaran 2015/2016 yang telah berpartisipasi dan bekerjasama dalam penelitian ini, serta seluruh pihak yang telah membantu penelitian ini.

\section{REFERENSI}

[1] Amir, M. T. 2009. Inovasi Pendidikan Melalu Problem Based Learning. Jakarta: Kencana Prenada Media Group.

[2] Hanafiah dan Suhana, C. 2009. Konsep Strategi Pembelajaran. Bandung : Refika Aditama.

[3] Trianto. 2011. Mendesain Model Pembelajaran Inovatif Progresif. Jakarta: Kencana Predana Media Group.

[4] Iskandar, S. M. 2015. Pendekatan Pembelajaran Sains Berbasis Konstruktivis. Malang: Media Nusantara Kreatif.

[5] Nur, M. 2005. Pembelaaran Kooperatif. Departemen Pendidikan Nasional Direktorat Pendidikan Dasar dan Menengah Lembaga Penjamin Mutu Jawa Timur.

[6] Putra, S. R. 2013. Desain Belajar Mengajar Kreatif Berbasis Sains. Jakarta: IKAPI

[7] Wardoyo,S. M. 2013. Pembelajaran Berbasis Konstrukstivisme. Jakarta: Penerbit Alfabeta.
[8] Arends, R. I. 2004. Learning to Teach Sixth Edition. Newyork: McGraw Hill Companies Inc.

[9] Ormword, J. E. 2009. Psikologi Pendidikan: Membantu Siswa Tumbuh dan Berkembang. Jakarta: Penerbit Erlangga.

[10] Hill, W. F. 2011. Theories Of Learning. Bandung: Penerbit Nusa Media.

[11] Arends, R.I. 2008. Lerning To Teach: Belajar untuk Mengajar Edisi Ketujuh/Jilid I. Diterjemahkan oleh Helly Prajitno Soetjipto dan Sri Mulyantini Soetjipto. Yogyakarta: Pustaka Pelajar.

[12] Zubaidah. 2010. Penguasaan Konsep oleh Siswa Melalui Metode Problem Solving pada Konsep Sistem Respirasi (Eksperimen di Mts Negeri Cipondoh Tangerang). Skripsi dipublikasikan. Jakarta: Universitas Islam Negeri Syarif Hidayatullah.

[13] Silaban, Bajongga. 2014. Hubungan Antara Penguasaan Konsep Fisika dan Kreativitas dengan Kemampuan Memecahkan Masalah pada Materi Pokok Listrik Statis. Jurnal Penelitian Bidang Pendidikan. Vol 20 (1), 65-75.

[14] Anderson, L. W., dan Krathwohl, D.R. 2010. Kerangka Landasan Untuk Pembelajaran, Pengajaran, dan Asesmen: Revisi Taksonomi Pendidikan Bloom. Diterjemahkan oleh Agung Prihantoro. Yogyakarta: Pustaka Pelajar.

[15] Fisher, A. 2008. Bepikir Kritis: Sebuah Pengantar. Jakarta: Erlangga.

[16] Surya, H. 2013. Cara Belajar Orang Genius: Study Hard Belumlah Cukup Tanpa Didukung Study Smart. Jakarta: PT Gramedia.

[17] Ennis, R.H. 1996. Critical Thinking. USA: Prentice-Hall, Inc.

[18] Santrock, W.J. 2003. Adolescence. Jakarta: Penerbit Erlangga. 